УДК: 311

JEL Classification: C 15

Ю. С. ПРИДАННИКОВА,

аспірант Хмельницького

університету управління та права,

головний спечіаліст-економіст

Головного управління статистики

у Харківсъкій області

\title{
Можливості статистичних методів для дослідження взаємозв'язків суспільно-економічних явищ і процесів
}

Досліджено можливості застосування статистичних методів для кількісного вивчення залежсності суспільно-економічних явии та прочесів. Для статистичного аналізу взаємозв 'язків запропоновано використовувати поряд із методом кореляційнорегресійного аналізу метод статистичних рівнянь залежностей.

Ключові слова: статистичні методи, статистична методологія, взасмозв 'язок суспільно-економічних явищ та прочесів, метод кореляційно-регресійного аналізу, метод статистичних рівнянь залежностей.

Постановка проблеми. Для визначення місця країни на міжнародній арені необхідним є статистичне забезпечення управління національною економікою та розроблення науково обгрунтованої системи статистичних показників, зіставних 3 міжнародною статистичною інформацією. Тому пріоритетними напрямками державної політики у сфері статистики є запровадження статистичних процедур на основі методології, класифікацін̆ та реєстрів, гармонізованих зі стандартами СС і міжнародними стандартами.

В Україні організаційні засади здійснення державної статистичної діяльності регулюються Законом України "Про державну статистику" [1], відповідно до ст. 9 якого органи державної статистики здін̆снюють розроблення статистичної інформації згідно з переліком робіт, перюдичністю, у розрізі та в терміни, шо передбачені планом державних статистичних спостережень на відповідний рік, який затверджується Кабінетом Міністрів України або окремими його рішеннями, технологічною програмою державних статистичних спостережень, іншими планами, графіками, затвердженими Державною службою статистики України.

Впровадження нових методів статистичних досліджень $\epsilon$ індикатором розвитку статистики як фундаментальної науки, яка має різноманітний інструментарін̆ для вирішення завдань, шо стоять перед органами державної влади, та статистичного забезпечення управління економікою.

Методологічні основи статистичного аналізу взаємозв'язку суснільно-економічних явищ і процесів, зокрема економгічного зростання та матеріального добробуту, формуються на нідставі наявної статистичної методології та відповідної системи показників.

Сьогодні статистичний аналіз взаємозв'язку суспільно-економічних явищ і процесів потребує впровадження найкращого практичного досвіду, зокрема сучасної науково обгрунтованої методології та системи статистичних показників. Це актуалізує дослідження можливостей статистичних методів 3 метою вдосконалення методології дослідження взаємозв'язку суспільно-економічних явищ і процесів.

Аналіз останніх досліджень та публікацій. Питанням статистичного аналізу взаємозв 'язків суспільно-економічних явиш і процесів присвячено праці А. Головача [4], С. Герасименка [5], А. Єріної [5], О. Кулинича [6], Р. Кулинича [7], I. Манцурова [8], Н. Парфенцевої [9], О. Осауленка [10] та інших вчених. Проте і на сьогоднішній час залишаються невирішеними питання забезпечення достовірності характеристик взаємозв'язків суспільно-економгічних явищ і процесів при дослідженні нечисленних

(C) Ю. С. Приданникова, 2017 
сукупностей за даними варіаційних та динамічних рядів, а також розв'язання, поряд із прямою, оберненої статистичної задачі ${ }^{1}$

Метою статті $€$ аналіз можливостей статистичних методів та їх вибір для удосконалення методології дослідження кількісних аспектів взаємозв'язків суснільноекономічних явищ і процесів.

Викладення основного матеріалу дослідження. Для визначення взасмозв'язків суспільно-економічних явищ і процесів, які обумовлюють тенденції розвитку економіки, провідну роль відіграють вибір статистичних методів для вивчення залежностей між показниками економічного зростання та матеріального добробуту населення, їх комплексне оцінювання та прогнозування.

В залежності від мети статистичного дослідження та характеру вихідних даних застосовують такі математичні та статистичні методи:

1) математичні методи кількісної характеристики взаємозв'язків:

- кореляційний і регресійний аналіз:

- дослідження операцій і теорія масового обслуговування;

- економічна кібернетика;

- класичні методи елементарної математики;

- імітаційне моделювання;

- функціонально-ієрархічні (прогнозні сценарії);

- методи структурної аналогії;

- метод експертних оцінок;

2) статистичні методи кількісної характеристики взаємозв'язків:

- дисперсін̆ний аналіз;

- кореляційний аналіз;

- метод аналітичних групувань;

- рангова кореляція;

- комплексні статистичні коефіцієнти;

- статистичні рівняння залежностей;

- статистичні індекси:

- показники аналізу динаміки.

При виборі статистичних методів дослідження суспільно-економічних явищ необхідно враховувати їх взаємопов'язаність і взаємообумовленість. Будь-яке явище $\epsilon$ наслідком дії певної множини причин i, разом із тим, причиною інших явищ i процесів. Тому до статистичного вивчення взаємозв'язків економічних явищ та процесів нідійдемо комплексно, спробувавши класифікувати досить широке коло методів, які дозволяють їх кількісно вимірювати. На думку О. Кулинича та Р. Кулинича, “Об'єктивну оцінку стану та розвитку суспільно-економічних явищ і процесів можна забезпечити тільки застосуванням правильно підібраних статистичних та математичних методів. Ці методи перестають бути предметом інтересу у практичній діяльності у тих випадках, коли немає впевненості; якою мірою їх можна застосувати для вирішення конкретних завдань. В умовах значного прогресу в технології збирання й опрацювання статистичних даних кваліфіковане застосування статистичних та математичних методів істотно гальмується якраз недостатнім знанням методів та їх можливостей в оцінці інформаціï” [7, с. 5-7]. I далі: “Статистика тісно пов' язана з математикою, проте математика користується абстрактними теоремами, які не розглядають сніввідношення з реальною дійсністю. Дійсні ж процеси соціальних, економічних та інших явищ вивчає статистика. Це вимагає від неї не абстрактного опису дін̆сності, а нізнання складних умов $і$ чинників розвитку явищ та процесів" [7, с. 9].

В процесі статистичного вивчення причинно-наслідкових зв'язків між явищами вирішуються такі завдання [9]:

- встановлюється факт наявності зв'язку між явищами;

- виявляється напрям і форми зв'язків;

- перевіряється сутність зв'язку;

- вимірюеться стунінь щільності зв'язку;

- оцінюються ефекти впливу одних явиш на інші.

\footnotetext{
1 Розв'язання такої задачі дозволяе отримати відповідь на запитання: “Як змінитися значення
} чинника (чинників) при зміні результативної ознаки на одиницю чи іншу задану величину?". 
Висновки стосовно наявності сили і характеру впливу одних явищ на інші мають важливе значення для практичної діяльності. Перш за все, для обгрунтування управлінських рішень, прогнозування і регулювання складних суспільно-економгічних явищ і процесів на шляху до економічного зростання та матеріального добробуту населення.

Зв'язок між явищами i, як наслідок, показниками, що їх характеризують, за специфікою впливу поділяється на функціональний та стохастичний (статистичний). При функціональному, або жорстко детермінованому, зв'язку кожному можливому значенню незалежної ознаки $x$ відповідає одне або декілька точно визначених значень залежної ознаки у. Характерною особливістю функціональних зв'язків $є$ те, що в кожному окремому випадку відомий повний перелік факторів, які визначають значення залежної результативної ознаки, а також точний механізм їх впливу, який виражається певним рівнянням. Так, функціональні зв'язки характеризуються повною відповідністю між причиною і наслідком факторів і результативних ознак.

Функціональний зв язок можна відобразити формулою:

$\mathrm{c}=a+b$ (адитивний тип функціонального зв язку);

$\mathrm{c}=a \times b$ (мультиплікативний тип функціонального зв'язку)

На відміну від функціонального, стохастичний (статистичний) зв'язок являє собою зв'язок між величинами, при якому одна випадкова величина $y$ реагує на зміну іншої випадкової величини $x$ зміною закону розподілу. Це обумовлено тим, що залежна змінна, окрім досліджуваних залежних, знаходиться під впливом випадкових факторів. Характерною особливістю стохастичних зв'язків $\epsilon$ те, що вони проявляються в усій сукупності, а не в кожній ії одиниці:

$$
\hat{y}_{i}=f\left(x_{i}\right)+\xi_{i}
$$

де $\hat{y}_{i}$ - розрахункове значення результативної ознаки;

$f\left(x_{i}\right)$ - частина результативної ознаки, сформованої під впливом врахованих відомих факторних ознак;

$\xi_{i}$ - частина результативної ознаки, яка виникла внаслідок неконтрольованих або неврахованих факторів.

Окремим випадком стохастичного зв' язку є кореляційний зв' язок, який існує там, де взаємозалежні явища характеризуються тільки випадковими величинами і можуть бути парними (однофакторними) і множинними (багатофакторними). У випадку багатофакторного зв'язку усі фактори діють комплексно - одночасно і у взаємозв'язку.

Для кількісного вимірювання зв'язку, в залежності від комбінації різноманітних за статистичною природою факторних і результативних ознак, в статистиці використовується ряд прийомів і методів:

- метод аналітичних групувань;

- дисперсійний аналіз:

- рангова кореляція;

- кореляційний і регресін̆ний аналіз;

- комплексні статистичні коефіцієнти;

- статистичні рівняння залежностей;

- статистичні індекси;

- показники аналізу динаміки.

Використання того чи іншого методу залежить від цілей дослідження. наявної статистичної інформації і статистичної особливості ознак (кількісні, якісні альтернативні, номікальні, порядкові), між якими визначається напрямок і вимірюється сила зв'язку.

До найпростіших методів дослідження статистичних зв'язків належать метод зіставлення паралельних даних (або паралельних динамічних рядів, якщо залежність між факторними і результативними ознаками простежується у часі), графічний метод, метод аналітичних групувань та метод кореляційних таблиць

Для виявлення наявності і характеру кореляційного зв'язку між двома ознаками в статистиці використовується ряд методів. Встановити наявність стохастичного зв'язку, а також отримати уявлення про його характер і напрямок можна за допомогою 
зіставлення значень двох ознак (паралельних даних) досліджуваних статистичних одиниць значень $x$ і $y$ в кожному $3 n$ спостережень. Для цього одиниці спостереження необхідно розташувати від найменшого до найбільшого (або від найбільшого до найменшого) значень факторної ознаки $x$ (в залежності від еволюції процесу і цілей дослідження) і потім візуально порівняти поведінку результативної ознаки $y$. Зіставлення і аналіз розташованих таким чином рядів значень досліджуваних величин дозволяє встановити наявність зв язку і його напрямок.

Граффічний метод використовується для наочного представлення кореляційної залежності. Для цього, маючи $n$ взаємозалежних пар значень $x$ і $y$ та користуючись прямокутною системою координат, кожну таку пару зображують у вигляді точки на площині з координатами $x$ і $y$, утворюючи кореляційне поле, де розмішуеться емпірична лінія регресії. Візуально аналізуючи графік, можна припустити характер залежності між ознаками $x$ i $y$.

Для виявлення кореляційного зв'язку при великій кількості спостережень використовується метод аналітичних групувань. Цей метод потребує не тільки правильного визначення факторної ознаки, а й кількості і меж інтервалів груп. В цьому випадку типовість і постійність групових середніх залежить від кількості груп. На практиці аналітичні групування часто виконують за принципом рівних часток, що значно спрощує подальший аналіз зв'язків.

Для того, щоб виявити наявність зв'язку між двома ознаками, необхідно провести групування одиниць сукупності за факторною ознакою і для кожної виокремленої

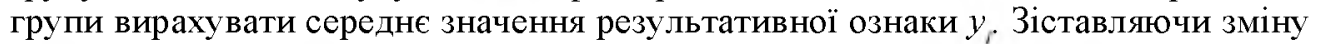
результативноі ознаки по мірі зміни факторної, можна виявити напрям, характер і щільність зв'язку між ними. Якщо результативна ознака $y$ залежить від факторної $x$, то у зміні середнього значення простежується певна закономірність.

Однак метод групування не дозволяе визначити форму (аналітичний вираз) впливу факторної ознаки на результативну. Факторна ознака, у відповідності з якою здійснюється аналітичне групування, може бути кількісною або атрибутивною, але результативна ознака завжди є кількісною.

Якшо обидві взаємозалежні ознаки кількісні, то за даними аналітичних групувань можна не тільки встановити наявність кореляційного зв'язку, а й визначити, як зміниться результативна ознака $y$ при зміні факторної $x$ від однієї групи до іншої. Ефект впливу $x$ на $y$ для $j$-ої групи визначається відношенням приростів групових середніх взаємозалежних ознак.

Метод кореляційних таблиць передбачає комбіиаційний розподіл одиниць сукупності за двома кількісними ознаками. Така таблиця спряженості будується за типом шахової, тобто в нідметі таблиці виділяються групи за факторною ознакою $x$, а в присудку таблиці - за результативною $y$. У клітинках таблиці на перетині $x$ i $y$ показується число випадків сумісноі появи ознак кожного значення $x$ з відповідним значенням $y$. Висновок про наявність і напрямок зв язку можна зробити за зовнішнім видом таблиці, тобто за розташуванням у ній часток.

Якщо частки розташовані у клітинках таблиці хаотично, то частіше за все це свідчить про відсутність зв 'язку між ознаками групування або про незначну залежність. Якщо частки сконщентровані ближче до однієї з діагоналей і центру таблиці, утворюючи свого роду еліпс, то майже завжди це $\epsilon$ свідченням наявності залежності між $x$ i $y$, близыкої до лінійної. Розташування по діагоналі з верхнього лівого кута в нижній правий свідчить про наявність прямого лінійного зв'язку, а з нижнього лівого кута у верхній правий - оберненого.

За даними кореляційної таблиці можна проаналізувати також залежності формування групових середніх аналогічно методу аналітичних групувань. На основі аналітичних групувань і кореляційних таблиць можна не тільки виявити наявність залежності між двома взаємопов' язаними показниками, а й виміряти щільність цього зв'язку, зокрема за допомогою емніричного кореляційного відношення:

$$
\eta=\sqrt{\frac{\sigma_{M, 2 .}^{2}}{\sigma_{3 a z .}^{2}}},
$$


де $\sigma_{\text {m.2. }}^{2}=\frac{\sum_{j=1}^{m}\left(\overline{y_{j}}-\bar{y}\right)^{2} \times f_{j}}{\sum \hat{f}_{j}}-$ міжгрупова дисперсія,

$\sigma_{s a z .}^{2}=\frac{\sum \sum\left(y_{i j}-y_{\text {saz. }}\right) \times f_{i j}}{\sum \sum f_{i j}}-$ загальна дисперсія.

Міра щільності зв`язку на основі застосування рангової кореляції визначається за формулою:

$$
\varsigma=1-\frac{6 \sum d^{2}}{n\left(n^{2}-1\right)},
$$

де $d=R_{x}-R_{y}$, тобто різниця між рангами взаємозалежних ознак $x$ i $y$ в окремих одиницях сукупності;

$n$ - число взаємозалежних пар значень $x$ і $y$.

Якщо зв'язок між явищами повний прямий, то ранги по $x$ i по $y$ співпадуть i $\sum d^{2}=0$, тоді $\varsigma=1$. Якщо зв'язок повний обернений, то ранги по $x$ знаходяться в оберненому напрямку рангам по $y$, тоді $\varsigma=-1$. Якщо зв'язок відсутній, то $\varsigma=0$.

Окрім того, щільність зв'язку за методом рангової кореляції можна вирахувати за допомогою коефіцієнта рангової кореляції Кендела:

$$
\tau=\frac{s}{\frac{1}{2} n(n-1)},
$$

де $s$ - сума балів, якщо балом +1 оцінюється пара рангів, які мають однаковий порядок, а балом -1 - пара рангів з оберненим порядком.

Перевірка адекватності регресійної моделі може бути доповнена кореляційним аналізом.

При ліиійній формі рівняння застосовується лінійний (парний) коефіцієнт кореляції:

$$
r=\frac{\overline{x y}-\overline{x y}}{\sigma_{x} \sigma_{y}}
$$

Кількісне значення коефіцієнта детермінації $\left(r^{2}\right)$ відображає частку загальної варіації результативної ознаки $y$, пояснювану зміною функщії регресії $f(x)$.

Багатофакторний кореляційний і регресійний аналіз дозволяє оцінити міру впливу на досліджуваний результативний показник кожного фактора при фіксованому положенні інших факторів, а також при будь-яких можливих комбінаціях факторів 3 визначеним ступенем точності знайти теоретичне значення цього показника:

$$
y=f\left(x_{1}, x_{2}, x_{3}, \ldots, x_{n}\right)+\xi
$$

Після вибору типу апроксимуючої функщії проводиться багатофакторний кореляційний і регресійний аналіз, задачею якого є побудова рівняння регресії і знаходження його невідомих параметрів $a_{0}, a_{1}, \ldots, a_{n}$.

Оцінка значимості простої лінійної регресії здійснюється за допомогою $t$-критерію Стьюдента. Розрахункове значення $t$-критерію для параметрів $a_{\theta}, a_{l}$ визначається так:

де $\sigma_{\text {ocm. }}=\sqrt{\sum(y-\hat{y})^{2} / n}$;

$$
t_{a_{0}}=\left|a_{0}\right| \frac{\sqrt{n-2}}{\sigma_{o c m .}} ; t_{a_{1}}=\left|a_{1}\right| \frac{\sqrt{n-2}}{\sigma_{o c m .}} \sigma_{x},
$$

$\sigma_{\text {ocm. }}=\sqrt{\sum(y-\hat{y})^{2} / n} ;$ або $\sigma_{x}=\sqrt{\overline{x^{2}}-(x)^{2}}$.

Комплексні статистичпі коефіцієнти абсолютних, відносних і середніх величин статики та динаміки та комплексні статистичні коефіцієнти відносних величин виконання планів (завдань, нормативів) використовуються для своєчасної та об'єктивної 
УДК: 311

JEL Classification: C 15

Ю. С. ПРИДАННИКОВА,

аспірант Хмельницького

університету управління та права,

головний спечіаліст-економіст

Головного управління статистики

у Харківсъкій області

\section{Можливості статистичних методів для дослідження взаємозв'язків суспільно-економічних явищ і процесів}

Досліджено можливості застосування статистичних методів для кількісного вивчення залежсності суспільно-економічних явии та прочесів. Для статистичного аналізу взаємозв 'язків запропоновано використовувати поряд із методом кореляційнорегресійного аналізу метод статистичних рівнянь залежностей.

Ключові слова: статистичні методи, статистична методологія, взасмозв 'язок суспільно-економічних явищ та прочесів, метод кореляційно-регресійного аналізу, метод статистичних рівнянь залежностей.

Постановка проблеми. Для визначення місця країни на міжнародній арені необхідним є статистичне забезпечення управління національною економікою та розроблення науково обгрунтованої системи статистичних показників, зіставних 3 міжнародною статистичною інформацією. Тому пріоритетними напрямками державної політики у сфері статистики є запровадження статистичних процедур на основі методології, класифікацін̆ та реєстрів, гармонізованих зі стандартами СС і міжнародними стандартами.

В Україні організаційні засади здійснення державної статистичної діяльності регулюються Законом України "Про державну статистику" [1], відповідно до ст. 9 якого органи державної статистики здін̆снюють розроблення статистичної інформації згідно з переліком робіт, перюдичністю, у розрізі та в терміни, шо передбачені планом державних статистичних спостережень на відповідний рік, який затверджується Кабінетом Міністрів України або окремими його рішеннями, технологічною програмою державних статистичних спостережень, іншими планами, графіками, затвердженими Державною службою статистики України.

Впровадження нових методів статистичних досліджень $\epsilon$ індикатором розвитку статистики як фундаментальної науки, яка має різноманітний інструментарін̆ для вирішення завдань, шо стоять перед органами державної влади, та статистичного забезпечення управління економікою.

Методологічні основи статистичного аналізу взаємозв'язку суснільно-економічних явищ і процесів, зокрема економгічного зростання та матеріального добробуту, формуються на нідставі наявної статистичної методології та відповідної системи показників.

Сьогодні статистичний аналіз взаємозв'язку суспільно-економічних явищ і процесів потребує впровадження найкращого практичного досвіду, зокрема сучасної науково обгрунтованої методології та системи статистичних показників. Це актуалізує дослідження можливостей статистичних методів 3 метою вдосконалення методології дослідження взаємозв'язку суспільно-економічних явищ і процесів.

Аналіз останніх досліджень та публікацій. Питанням статистичного аналізу взаємозв 'язків суспільно-економічних явиш і процесів присвячено праці А. Головача [4], С. Герасименка [5], А. Єріної [5], О. Кулинича [6], Р. Кулинича [7], I. Манцурова [8], Н. Парфенцевої [9], О. Осауленка [10] та інших вчених. Проте і на сьогоднішній час залишаються невирішеними питання забезпечення достовірності характеристик взаємозв'язків суспільно-економгічних явищ і процесів при дослідженні нечисленних

(C) Ю. С. Приданникова, 2017 
сукупностей за даними варіаційних та динамічних рядів, а також розв'язання, поряд із прямою, оберненої статистичної задачі ${ }^{1}$

Метою статті $€$ аналіз можливостей статистичних методів та їх вибір для удосконалення методології дослідження кількісних аспектів взаємозв'язків суснільноекономічних явищ і процесів.

Викладення основного матеріалу дослідження. Для визначення взасмозв'язків суспільно-економічних явищ і процесів, які обумовлюють тенденції розвитку економіки, провідну роль відіграють вибір статистичних методів для вивчення залежностей між показниками економічного зростання та матеріального добробуту населення, їх комплексне оцінювання та прогнозування.

В залежності від мети статистичного дослідження та характеру вихідних даних застосовують такі математичні та статистичні методи:

1) математичні методи кількісної характеристики взаємозв'язків:

- кореляційний і регресійний аналіз:

- дослідження операцій і теорія масового обслуговування;

- економічна кібернетика;

- класичні методи елементарної математики;

- імітаційне моделювання;

- функціонально-ієрархічні (прогнозні сценарії);

- методи структурної аналогії;

- метод експертних оцінок;

2) статистичні методи кількісної характеристики взаємозв'язків:

- дисперсін̆ний аналіз;

- кореляційний аналіз;

- метод аналітичних групувань;

- рангова кореляція;

- комплексні статистичні коефіцієнти;

- статистичні рівняння залежностей;

- статистичні індекси:

- показники аналізу динаміки.

При виборі статистичних методів дослідження суспільно-економічних явищ необхідно враховувати їх взаємопов'язаність і взаємообумовленість. Будь-яке явище $\epsilon$ наслідком дії певної множини причин i, разом із тим, причиною інших явищ i процесів. Тому до статистичного вивчення взаємозв'язків економічних явищ та процесів нідійдемо комплексно, спробувавши класифікувати досить широке коло методів, які дозволяють їх кількісно вимірювати. На думку О. Кулинича та Р. Кулинича, “Об'єктивну оцінку стану та розвитку суспільно-економічних явищ і процесів можна забезпечити тільки застосуванням правильно підібраних статистичних та математичних методів. Ці методи перестають бути предметом інтересу у практичній діяльності у тих випадках, коли немає впевненості; якою мірою їх можна застосувати для вирішення конкретних завдань. В умовах значного прогресу в технології збирання й опрацювання статистичних даних кваліфіковане застосування статистичних та математичних методів істотно гальмується якраз недостатнім знанням методів та їх можливостей в оцінці інформаціï” [7, с. 5-7]. I далі: “Статистика тісно пов' язана з математикою, проте математика користується абстрактними теоремами, які не розглядають сніввідношення з реальною дійсністю. Дійсні ж процеси соціальних, економічних та інших явищ вивчає статистика. Це вимагає від неї не абстрактного опису дін̆сності, а нізнання складних умов $і$ чинників розвитку явищ та процесів" [7, с. 9].

В процесі статистичного вивчення причинно-наслідкових зв'язків між явищами вирішуються такі завдання [9]:

- встановлюється факт наявності зв'язку між явищами;

- виявляється напрям і форми зв'язків;

- перевіряється сутність зв'язку;

- вимірюеться стунінь щільності зв'язку;

- оцінюються ефекти впливу одних явиш на інші.

\footnotetext{
1 Розв'язання такої задачі дозволяе отримати відповідь на запитання: “Як змінитися значення
} чинника (чинників) при зміні результативної ознаки на одиницю чи іншу задану величину?". 
Висновки стосовно наявності сили і характеру впливу одних явищ на інші мають важливе значення для практичної діяльності. Перш за все, для обгрунтування управлінських рішень, прогнозування і регулювання складних суспільно-економгічних явищ і процесів на шляху до економічного зростання та матеріального добробуту населення.

Зв'язок між явищами i, як наслідок, показниками, що їх характеризують, за специфікою впливу поділяється на функціональний та стохастичний (статистичний). При функціональному, або жорстко детермінованому, зв'язку кожному можливому значенню незалежної ознаки $x$ відповідає одне або декілька точно визначених значень залежної ознаки у. Характерною особливістю функціональних зв'язків $є$ те, що в кожному окремому випадку відомий повний перелік факторів, які визначають значення залежної результативної ознаки, а також точний механізм їх впливу, який виражається певним рівнянням. Так, функціональні зв'язки характеризуються повною відповідністю між причиною і наслідком факторів і результативних ознак.

Функціональний зв язок можна відобразити формулою:

$\mathrm{c}=a+b$ (адитивний тип функціонального зв язку);

$\mathrm{c}=a \times b$ (мультиплікативний тип функціонального зв'язку)

На відміну від функціонального, стохастичний (статистичний) зв'язок являє собою зв'язок між величинами, при якому одна випадкова величина $y$ реагує на зміну іншої випадкової величини $x$ зміною закону розподілу. Це обумовлено тим, що залежна змінна, окрім досліджуваних залежних, знаходиться під впливом випадкових факторів. Характерною особливістю стохастичних зв'язків $\epsilon$ те, що вони проявляються в усій сукупності, а не в кожній ії одиниці:

$$
\hat{y}_{i}=f\left(x_{i}\right)+\xi_{i}
$$

де $\hat{y}_{i}$ - розрахункове значення результативної ознаки;

$f\left(x_{i}\right)$ - частина результативної ознаки, сформованої під впливом врахованих відомих факторних ознак;

$\xi_{i}$ - частина результативної ознаки, яка виникла внаслідок неконтрольованих або неврахованих факторів.

Окремим випадком стохастичного зв' язку є кореляційний зв' язок, який існує там, де взаємозалежні явища характеризуються тільки випадковими величинами і можуть бути парними (однофакторними) і множинними (багатофакторними). У випадку багатофакторного зв'язку усі фактори діють комплексно - одночасно і у взаємозв'язку.

Для кількісного вимірювання зв'язку, в залежності від комбінації різноманітних за статистичною природою факторних і результативних ознак, в статистиці використовується ряд прийомів і методів:

- метод аналітичних групувань;

- дисперсійний аналіз:

- рангова кореляція;

- кореляційний і регресін̆ний аналіз;

- комплексні статистичні коефіцієнти;

- статистичні рівняння залежностей;

- статистичні індекси;

- показники аналізу динаміки.

Використання того чи іншого методу залежить від цілей дослідження. наявної статистичної інформації і статистичної особливості ознак (кількісні, якісні альтернативні, номікальні, порядкові), між якими визначається напрямок і вимірюється сила зв'язку.

До найпростіших методів дослідження статистичних зв'язків належать метод зіставлення паралельних даних (або паралельних динамічних рядів, якщо залежність між факторними і результативними ознаками простежується у часі), графічний метод, метод аналітичних групувань та метод кореляційних таблиць

Для виявлення наявності і характеру кореляційного зв'язку між двома ознаками в статистиці використовується ряд методів. Встановити наявність стохастичного зв'язку, а також отримати уявлення про його характер і напрямок можна за допомогою 
зіставлення значень двох ознак (паралельних даних) досліджуваних статистичних одиниць значень $x$ і $y$ в кожному $3 n$ спостережень. Для цього одиниці спостереження необхідно розташувати від найменшого до найбільшого (або від найбільшого до найменшого) значень факторної ознаки $x$ (в залежності від еволюції процесу і цілей дослідження) і потім візуально порівняти поведінку результативної ознаки $y$. Зіставлення і аналіз розташованих таким чином рядів значень досліджуваних величин дозволяє встановити наявність зв язку і його напрямок.

Граффічний метод використовується для наочного представлення кореляційної залежності. Для цього, маючи $n$ взаємозалежних пар значень $x$ і $y$ та користуючись прямокутною системою координат, кожну таку пару зображують у вигляді точки на площині з координатами $x$ і $y$, утворюючи кореляційне поле, де розмішуеться емпірична лінія регресії. Візуально аналізуючи графік, можна припустити характер залежності між ознаками $x$ i $y$.

Для виявлення кореляційного зв'язку при великій кількості спостережень використовується метод аналітичних групувань. Цей метод потребує не тільки правильного визначення факторної ознаки, а й кількості і меж інтервалів груп. В цьому випадку типовість і постійність групових середніх залежить від кількості груп. На практиці аналітичні групування часто виконують за принципом рівних часток, що значно спрощує подальший аналіз зв'язків.

Для того, щоб виявити наявність зв'язку між двома ознаками, необхідно провести групування одиниць сукупності за факторною ознакою і для кожної виокремленої

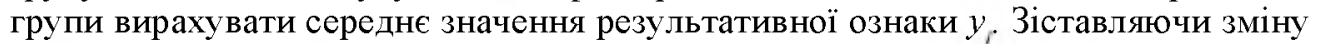
результативноі ознаки по мірі зміни факторної, можна виявити напрям, характер і щільність зв'язку між ними. Якщо результативна ознака $y$ залежить від факторної $x$, то у зміні середнього значення простежується певна закономірність.

Однак метод групування не дозволяе визначити форму (аналітичний вираз) впливу факторної ознаки на результативну. Факторна ознака, у відповідності з якою здійснюється аналітичне групування, може бути кількісною або атрибутивною, але результативна ознака завжди є кількісною.

Якшо обидві взаємозалежні ознаки кількісні, то за даними аналітичних групувань можна не тільки встановити наявність кореляційного зв'язку, а й визначити, як зміниться результативна ознака $y$ при зміні факторної $x$ від однієї групи до іншої. Ефект впливу $x$ на $y$ для $j$-ої групи визначається відношенням приростів групових середніх взаємозалежних ознак.

Метод кореляційних таблиць передбачає комбіиаційний розподіл одиниць сукупності за двома кількісними ознаками. Така таблиця спряженості будується за типом шахової, тобто в нідметі таблиці виділяються групи за факторною ознакою $x$, а в присудку таблиці - за результативною $y$. У клітинках таблиці на перетині $x$ i $y$ показується число випадків сумісноі появи ознак кожного значення $x$ з відповідним значенням $y$. Висновок про наявність і напрямок зв язку можна зробити за зовнішнім видом таблиці, тобто за розташуванням у ній часток.

Якщо частки розташовані у клітинках таблиці хаотично, то частіше за все це свідчить про відсутність зв 'язку між ознаками групування або про незначну залежність. Якщо частки сконщентровані ближче до однієї з діагоналей і центру таблиці, утворюючи свого роду еліпс, то майже завжди це $\epsilon$ свідченням наявності залежності між $x$ i $y$, близыкої до лінійної. Розташування по діагоналі з верхнього лівого кута в нижній правий свідчить про наявність прямого лінійного зв'язку, а з нижнього лівого кута у верхній правий - оберненого.

За даними кореляційної таблиці можна проаналізувати також залежності формування групових середніх аналогічно методу аналітичних групувань. На основі аналітичних групувань і кореляційних таблиць можна не тільки виявити наявність залежності між двома взаємопов' язаними показниками, а й виміряти щільність цього зв'язку, зокрема за допомогою емніричного кореляційного відношення:

$$
\eta=\sqrt{\frac{\sigma_{M, 2 .}^{2}}{\sigma_{3 a z .}^{2}}},
$$


де $\sigma_{\text {m.2. }}^{2}=\frac{\sum_{j=1}^{m}\left(\overline{y_{j}}-\bar{y}\right)^{2} \times f_{j}}{\sum \hat{f}_{j}}-$ міжгрупова дисперсія,

$\sigma_{s a z .}^{2}=\frac{\sum \sum\left(y_{i j}-y_{\text {saz. }}\right) \times f_{i j}}{\sum \sum f_{i j}}-$ загальна дисперсія.

Міра щільності зв`язку на основі застосування рангової кореляції визначається за формулою:

$$
\varsigma=1-\frac{6 \sum d^{2}}{n\left(n^{2}-1\right)},
$$

де $d=R_{x}-R_{y}$, тобто різниця між рангами взаємозалежних ознак $x$ i $y$ в окремих одиницях сукупності;

$n$ - число взаємозалежних пар значень $x$ і $y$.

Якщо зв'язок між явищами повний прямий, то ранги по $x$ i по $y$ співпадуть i $\sum d^{2}=0$, тоді $\varsigma=1$. Якщо зв'язок повний обернений, то ранги по $x$ знаходяться в оберненому напрямку рангам по $y$, тоді $\varsigma=-1$. Якщо зв'язок відсутній, то $\varsigma=0$.

Окрім того, щільність зв'язку за методом рангової кореляції можна вирахувати за допомогою коефіцієнта рангової кореляції Кендела:

$$
\tau=\frac{s}{\frac{1}{2} n(n-1)},
$$

де $s$ - сума балів, якщо балом +1 оцінюється пара рангів, які мають однаковий порядок, а балом -1 - пара рангів з оберненим порядком.

Перевірка адекватності регресійної моделі може бути доповнена кореляційним аналізом.

При ліиійній формі рівняння застосовується лінійний (парний) коефіцієнт кореляції:

$$
r=\frac{\overline{x y}-\overline{x y}}{\sigma_{x} \sigma_{y}}
$$

Кількісне значення коефіцієнта детермінації $\left(r^{2}\right)$ відображає частку загальної варіації результативної ознаки $y$, пояснювану зміною функщії регресії $f(x)$.

Багатофакторний кореляційний і регресійний аналіз дозволяє оцінити міру впливу на досліджуваний результативний показник кожного фактора при фіксованому положенні інших факторів, а також при будь-яких можливих комбінаціях факторів 3 визначеним ступенем точності знайти теоретичне значення цього показника:

$$
y=f\left(x_{1}, x_{2}, x_{3}, \ldots, x_{n}\right)+\xi
$$

Після вибору типу апроксимуючої функщії проводиться багатофакторний кореляційний і регресійний аналіз, задачею якого є побудова рівняння регресії і знаходження його невідомих параметрів $a_{0}, a_{1}, \ldots, a_{n}$.

Оцінка значимості простої лінійної регресії здійснюється за допомогою $t$-критерію Стьюдента. Розрахункове значення $t$-критерію для параметрів $a_{\theta}, a_{l}$ визначається так:

де $\sigma_{\text {ocm. }}=\sqrt{\sum(y-\hat{y})^{2} / n}$;

$$
t_{a_{0}}=\left|a_{0}\right| \frac{\sqrt{n-2}}{\sigma_{o c m .}} ; t_{a_{1}}=\left|a_{1}\right| \frac{\sqrt{n-2}}{\sigma_{o c m .}} \sigma_{x},
$$

$\sigma_{\text {ocm. }}=\sqrt{\sum(y-\hat{y})^{2} / n} ;$ або $\sigma_{x}=\sqrt{\overline{x^{2}}-(x)^{2}}$.

Комплексні статистичпі коефіцієнти абсолютних, відносних і середніх величин статики та динаміки та комплексні статистичні коефіцієнти відносних величин виконання планів (завдань, нормативів) використовуються для своєчасної та об'єктивної 
кількісної оцінки результатів господарсько-фіиансової діяльності підприємств і організацій за певний проміжок часу або на певну дату (автором методу комплексних статистичних коефіцієнтів $є$ проф. О. І. Кулинич [6]).

Сутність методу комплексних статистичних коефіцієнтів полягає у встановлені переліку показників господарсько-фінансової діяльності підприємств і оргапізацій, розрахунку комплексного показника та визначенні місця окремого піддпиємства чи організації в їх сукупності.

Комплексний коефіцієнт вагомості відхилень абсолютних, середніх та відносних показників дорівнює:

$$
K_{e}=\sum \frac{x_{\max }-x_{i}}{x_{\max }-x_{\min }}+\sum \frac{x_{i}-x_{\min }}{x_{\max }-x_{\min }}
$$

Комплексний коефіцієнт вагомості відхилень відносних величин виконання планів (прогнозних завдань, нормативів) визначається як:

$$
K_{\theta}=\sum \frac{100-x_{i} \leq 100}{100}+\sum\left(\frac{x_{\max } \succ 100-x_{i} \succ 100}{x_{\max } \succ 100}\right)^{\prime},
$$

де $K_{e}$ - комплексний коефіцієнт вагомості відхилень;

$x_{i}-$ значення показника господарсько-фінансової діяльності;

$x_{\text {min }}, x_{\text {mix }}$ - відповідно мінімальне та максимальне значення показника.

Зокрема, за допомогою комплексних коефіціснтів вагомості відхилень абсолютних та відносних показників можливо здін̆снити комплексну оцінку регіонів за їх впливом на середні для країни значення, а також для комплексної оцінки національної економіки в міжнародному порівнянні за результатами показників економічного зростання та матеріального добробуту населення.

Комплексний коефіцієнт вагомості відхилень відносних величин виконання планів (прогнозних завдань, нормативів) передбачає оцінки виконання планів, рівномірності виконання плапів виробництва (асортименту) і поставок продукції чи послуг та відносних величин виконання планових показників, прогнозних завдань чи нормативів господарсько-фінансової діяльності.

Розрахунки комплексної оцінки виконання плану показників господарськофінансової діяльності грунтуються на визначенні відхилень за такими формулами:

$$
\begin{gathered}
100-x_{i} \leq 100 ; \\
x_{\max } \succ 100-x_{i} \succ 100,
\end{gathered}
$$

де $x_{i} \leq 100, x_{i} \succ 100$ - значення відсотка виконання планового показника господарсько-фінансової діяльності окремого підприємства (організації), яке, відповідно, менше $100 \%$ та більше $100 \%$;

$x_{\max } \succ 100$ - максимальне значення темпу зростання відсотка виконання плану, завдання або нормативного показника господарсько-фінансової діяльності по сукупності нідприємств чи організації (більше ніж 100\%) [7, с. 57-75].

Статистичні рівняння залежностей - це статистичний метод аналізу причинних взаємозв язків між економічними явишами і процесами. На відміну від математичного методу кореляційного і регресійного аналізу, основою якого є лінійна алгебра, застосування методу статистичних рівнянь залежностей грунтується на обчисленні коефіцієнтів порівняння, які визначають через відношення окремих значень однойменної ознаки до його мінімального (при збільшенні значень ознаки) або максимального (при зменшенні) рівня.

Коефіцієнти порівняння вказують на стунінь зміни (збільшення чи зменшення) величини ознаки порівняно з прийнятою базою порівняння. На основі коефіцієнтів порівняння результативної та факторної ознак розраховують параметр рівняння залежності. На відміну від відомих у статистиці коефіцієнтів еластичності параметри рівняння залежності, які визначають методом відхилень, дають змогу врахувати не тільки вплив на результативну ознаку одного чинника, але і сукупну дію багатьох чинників [7, с. 90]. 
кількісної оцінки результатів господарсько-фіиансової діяльності підприємств і організацій за певний проміжок часу або на певну дату (автором методу комплексних статистичних коефіцієнтів $є$ проф. О. І. Кулинич [6]).

Сутність методу комплексних статистичних коефіцієнтів полягає у встановлені переліку показників господарсько-фінансової діяльності підприємств і оргапізацій, розрахунку комплексного показника та визначенні місця окремого піддпиємства чи організації в їх сукупності.

Комплексний коефіцієнт вагомості відхилень абсолютних, середніх та відносних показників дорівнює:

$$
K_{e}=\sum \frac{x_{\max }-x_{i}}{x_{\max }-x_{\min }}+\sum \frac{x_{i}-x_{\min }}{x_{\max }-x_{\min }}
$$

Комплексний коефіцієнт вагомості відхилень відносних величин виконання планів (прогнозних завдань, нормативів) визначається як:

$$
K_{\theta}=\sum \frac{100-x_{i} \leq 100}{100}+\sum\left(\frac{x_{\max } \succ 100-x_{i} \succ 100}{x_{\max } \succ 100}\right)^{\prime},
$$

де $K_{e}$ - комплексний коефіцієнт вагомості відхилень;

$x_{i}-$ значення показника господарсько-фінансової діяльності;

$x_{\text {min }}, x_{\text {mix }}$ - відповідно мінімальне та максимальне значення показника.

Зокрема, за допомогою комплексних коефіціснтів вагомості відхилень абсолютних та відносних показників можливо здін̆снити комплексну оцінку регіонів за їх впливом на середні для країни значення, а також для комплексної оцінки національної економіки в міжнародному порівнянні за результатами показників економічного зростання та матеріального добробуту населення.

Комплексний коефіцієнт вагомості відхилень відносних величин виконання планів (прогнозних завдань, нормативів) передбачає оцінки виконання планів, рівномірності виконання плапів виробництва (асортименту) і поставок продукції чи послуг та відносних величин виконання планових показників, прогнозних завдань чи нормативів господарсько-фінансової діяльності.

Розрахунки комплексної оцінки виконання плану показників господарськофінансової діяльності грунтуються на визначенні відхилень за такими формулами:

$$
\begin{gathered}
100-x_{i} \leq 100 ; \\
x_{\max } \succ 100-x_{i} \succ 100,
\end{gathered}
$$

де $x_{i} \leq 100, x_{i} \succ 100$ - значення відсотка виконання планового показника господарсько-фінансової діяльності окремого підприємства (організації), яке, відповідно, менше $100 \%$ та більше $100 \%$;

$x_{\max } \succ 100$ - максимальне значення темпу зростання відсотка виконання плану, завдання або нормативного показника господарсько-фінансової діяльності по сукупності нідприємств чи організації (більше ніж 100\%) [7, с. 57-75].

Статистичні рівняння залежностей - це статистичний метод аналізу причинних взаємозв язків між економічними явишами і процесами. На відміну від математичного методу кореляційного і регресійного аналізу, основою якого є лінійна алгебра, застосування методу статистичних рівнянь залежностей грунтується на обчисленні коефіцієнтів порівняння, які визначають через відношення окремих значень однойменної ознаки до його мінімального (при збільшенні значень ознаки) або максимального (при зменшенні) рівня.

Коефіцієнти порівняння вказують на стунінь зміни (збільшення чи зменшення) величини ознаки порівняно з прийнятою базою порівняння. На основі коефіцієнтів порівняння результативної та факторної ознак розраховують параметр рівняння залежності. На відміну від відомих у статистиці коефіцієнтів еластичності параметри рівняння залежності, які визначають методом відхилень, дають змогу врахувати не тільки вплив на результативну ознаку одного чинника, але і сукупну дію багатьох чинників [7, с. 90]. 
Проте для вибору методів статистичного дослідження взаємозв'язку між економічними явищами та процесами врахуємо переваги і недоліки вищевикладених методів.

Недарма один з розділів книги Ф. Мостеллера й Дж. Тьюкі має назву “Біди регресін̆них коефіцієнтів" [13, с. 43]. "Найбільш виразно втрата економічною інфформацією первозданного традиційного змісту виявляється за кібернетичного підходу до розв' язання економічних задач, ущільнення інформації методами багатовимірного аналізу, методом стандартизованих групувань тощо, що працює на прихованих противників математичної статистики. Проте синтезована, узагальнена інформація при цьому не пориває з економічним змістом, а набуває нового, поглибленого змісту, доступного для розуміння з позицій так званих реальностей другого порядку" [11, С. 99-100].

Відомий представник статистичної науки А. Боярський наголошував, що "стадія так званої інтерпретації результатів... факторного аналізу, який перейшов у інші галузі iз психології, де наукове нізнання все ще перебуває на неминучій у будь-якій науці стадії збирання емніричних фактів і спроб їх систематизації' і водночас указав, що економісти вже не мають потреби в перетвореннях цього аналізу [11, с. 172].

Відомий статистик Т. Козлов зазначив, що в науковій і навчальній літературі зі статистики звичайно не приділяється належна увага ситуаціям, коли після включення в багатофакторну модель якогось фактора або вилучення з неї певної факторної ознаки змінюються як розміри параметрів регресії, так і знаки при них $[11$, с. 95$]$.

Так, ще в 1969 році у фундаментальній науковін̆ праці “Статистика" А. Боярський назвав "недоречностями" від' ємні коефіцієнти при сприятливих для залежної змінної факторних змінних або додатні при несприятливих, допустивши, що вони можуть мати '... пояснення в чудернацькому сплетінні взаємозалежностей факторів і результату" [12, с. 251].

Зокрема, на його думку, якщо фактори А і В впливають сприятливо, але перебувають в оберненій кореляційній залежності, коефіцієнт регресії при змінній А може виявитися від'ємним, якщо фактор В у регресін̆ному рівнянні відсутній. У цьому випадку, як зазначає А. Боярський, збільшення факторної ознаки А справляє на залежну змінну як сприятливий вплив - безпосередньо, так і несприятливий - через зменшення B $[12$, c. $251-252]$.

Вагоме місце серед методів статистичного дослідження взаємозв'язків між суспільно-економічними явищами і процесами належить методу статистичних індексів. С. С. Герасименко, А. В. Головач, А. М. Єріна пропонують виділити дві функції індексів: "синтетичну, пов'язану з побудовою узагальнюючих характеристик динаміки чи просторових порівнянь та аналітичну, спрямовану на вивчення закономірностей динаміки, взаємозв'язків між показниками, структурних зрушень" [5, с. 139].

Агрегатні індекси дозволяють оцінити (виміряти) функціональний тип зв'язків, а також прогнозувати соціально-економічні явища і процеси, наприклад для оцінки впливу прогнозованого рівня інфляції на формування доходів населення [13]

Окрім того, в статистичних дослідженнях взаємозв'язку між суспільноекономічними явищами і процесами запропоновані методи застосовуються при вивченні того чи іншого явища або процесу в динаміці. Як вже зазначалося, невизначеність явищ і процесів у природі $\epsilon$ їх внутрішньою властивістю. Вивчення взаємозв'язку між цими явищами і процесами в динаміці, передбачення перспектив їх подальшого розвитку, прийняття оптимальних управлінсыких рішень повинні опиратися на застосування таких методів, які б умовах невизначеності забезпечували надін̆ність висновків.

Одним із напрямків статистичного вивчення взаємозв' язків є моделювання і прогнозування динаміки соціально-економічних явищ і процесів. Модель встановлює відповідність між сукупністю факторів і гіпотезами, імітуючи механізм формування закономірностей. Прогноз служить інструментом мінімізації невизначеності $1 \epsilon$ науково обгрунтованим висновком щодо майбутнього розвитку процесів, його перспектив, можливих наслідків управлінсыких рішень.

Для статистичного вивчення динаміки процесу необхідно, щоб інформація була повною, зіставною, динамічний ряд мав достатню довжину, а також унеможливлював аномальні значення. 
При проведенні статистичного аналізу динаміки явищ і прогнозування необхідно враховувати тренд, сезонну компоненту, циклічну компоненту, випадкову компоненту. Трендом вважають зміну, яка визначас загальний напрямок розвитку - основну тенденцію ряду; це систематична складова довгострокової дії. Поряд із довгостроковими тенденціями у динамічних рядах часто виникають регулярні коливання перюдична складова рядів динаміки. Коли перюд коливань не перевищує року, він вважається сезонним. При великому перюді коливань в динамічних рядах має місце циклічна складова (наприклад, цикл ділової активності). Якшо із динамічного ряду вилучити тренд і перюдичні складові, то залишиться нерегулярна компонента. Фактори, нід дією яких формується нерегулярна компонента, поділяються на два види: фактори раптової дії (світова криза, лиха, катастрофи) та поточні фактори (шум).

Висновки і подальıі дос гідження. Статистичні рівняння залежностей як метод кількісного оцінювання взаємозв ' язку між соціально-економічними явищами і процесами дозволяє вирішити обернену задачу, тобто визначення рівня чинників та величину ї зміни при зміні результативної ознаки на одиницю чи іншу величину (планову, нормативну чи прогнозовану), а також визначити поведінку чинників при форму ванні рівня соціально-економічного явища, в тому числі для оцінювання взаємозв язку між економічним зростанням та матеріальним добробутом населення.

Метод статистичних рівнянь залежностей дістав широке міжнародне визнання, оскільки він має істотну перевагу - вирішує обернену економічну чи технічну задачу та застосовується поряд із математичним методом кореляційно-регресійного аналізу для вивчення взаємозв'язків у нечисленних та численних сукупностях, а також при наявності кореляційної чи функціональної залежності.

Разом із тим, застосування методу статистичних рівнянь залежностей забезпечено розробленням комп'ютерної програми "Метод статистичних рівнянь залежностей", що $є$ сучасним загальнодоступним інструментом у розв'язанні широкого кола задач за вихідними даними варіаційних рядів при нечисленній (до 20 одинишь) та численній сукупності одиниць спостереження та за вихідними даними рядів динаміки [6].

Враховуючи вищевикладене, метод статистичних рівнянь залежностей відповідає сучасним вимогам та потребам статистичного аналізу суспільно-економічних явищ $i$ процесів, має науково обгрунтовану методологію, широко використовується науковцями у дослідженнях [6], є статистичним інструментом, який зарекомендував себе на "ринку" методів статистичного дослідження взаємозв"язків між економічними явищами і процесами. Цей метод має згадані вище переваги порівняно з іншими математичними та статистичними методами, зокрема є альтернативою кореляційному та регресійному аналізу і надає більш широкі можливості для використання в статистичних дослідженнях при нечисленних сукупностях (від трьох одиниць).

Використання результатів статистичного аналізу взаємозв'язку суспільноекономічних явищ та процесів дозволяє реалізовувати державну політику та приймати обгрунтовані рішення для досягнення стратегічних цілей й пріоритетів, а також знаходити потенційні резерви економічного зростання та матеріального добробуту населення.

Перспективою подальших досліджень у с()ері дослідження і аналізу можливостей методів статистичних досліджень $\epsilon$ формування системи показників для вивчення кількісної сторони масових суснільно-економічних явищ і процесів, що характеризують зокрема залежність між економічним зростанням та матеріальним добробутом населення.

\section{Список використаних джерел}

1. Закон України "Про державну статистику" від 17.09.1992 р. // Відомості Верховної ради України. 1992. № 43. Ст. 608.

2. Звіт про результати діяльності Державної служби статистики України за 2015 рік. Державна служба статистики України. URL: http://data.gov.ua/file/20842/ download?token $=6 \mathrm{GGRekZK}$

3. Про затвердження Стратегії розвитку державної статистики на період до 2017 року: розпорядження Кабінету Міністрів України № 145-р від 20.03.2013 p. URL: http://zakon5.rada.gov.ua/laws/show/145-2013-\%D1\%80. 
4. Головач, А. В., Захожай В. Б., Головач Н. А. Статистичне забезпечення управління економікою: прикладна статистика: навч. посіб. К.: КНЕУ, 2005. 333 с.

5. Герасименко С. С. та ін. Статистика: підруч. 2-е вид., перероб. і доп. К.: КНЕУ, 2000. $467 \mathrm{c}$.

6. Кулинич О. І. Статистична оцінка залежностей показників інтенсивності регіонального розвитку // Статистична оцінка соціально-економічного розвитку: зб. текстів доповідей за матеріалами Всеукраїнської наук.-практ. конф., 21 травня 2015 р. Хмельницький: Хмельницький університет управління та права, 2015. C. $10-27$.

7. Кулинич О. І., Кулинич Р. О. Теорія статистики: підруч. 7-е вид., перероб. і доп. К.: Знання, 2015. 239 с.

8. Манщуров I. Г. Статистика економгічного зростання та конкурентоспроможності країни: монограф. К.: КНЕУ, 2006. 392 с.

9. Статистика ринків: підручн. для вищ. навч. закл. // За наук. ред. Н. О. Парфенцевої. К.: 1нформ.-аналіт. агентство, 2007. 863 с.

10. Осауленко, О. Г. Національна статистична система: стратегічне планування, методологія та оргапізація: монограф. К.: 1нформ.-аналіт. агентство, 2008. 415 с.

11. Вопросы статистической методологии и статистико-экономического анализа: материалы Всесоюз. науч. совещ. М.: Статистика, 1980. 207 с.

12. Боярский А. Я. и др. Статистика: учебник. М.: Статистика, 1969. 567 с.

13. Prydannykova Y. Application of an index method for assessment of impact of inflation on expected household income. Хмельницыкий: Вид-во ун-ту "У ніверситетські наукові записки", 2017. 320 c.

14. Капленко Г. В. 3 історії висвітлення у статистичній та економгіній літературі питання про логіко-економічний зміст параметрів регресії // Статистична оцінка соціально-економічного розвитку: зб. текстів доповідей за матеріалами Всеукраїнської наук.-практ. конф., 26 травня 2017 р. Хмельницький: Хмельницький упіверситет управління та права, 2017. С. 30-32.

15. Мостеллер Ф., Тьюки Дж. Анализ данных и регрессия: в 2 вып. Пер. с англ. М.: Финансы и статистика, 1982. Вып. 2. 238 с.

\author{
Ю.Е. ПРИДАННИКОВА, \\ аспирант Хмельницкого \\ университета управления и права, \\ главный специалист-экономист \\ Главного управления статистики \\ в Харьковской области
}

\title{
Возможности статистических методов для исследования взаимосвязи общественно-экономических явлений и процессов
}

Исследованы возможности применения статистических методов для количественного изучения взаимосвязей общественно-экономических явлений и прочессов. Для статистического анализа взаимосвязей в статье предложено использовать наряду с методом корреляционно-регрессионного анализа метод статистических уравнений зависимостей.

Ключевые слова: статистические методы, статистическая методология, взаимосвязь общественно-экономических явлений и прочессов, метод корреляционнорегрессионного анализа, метод статистических уравнений зависимостей. 
YU. E. PRYDANNYKOVA,

Post-graduate student, Khmelnytskyi University of Management and Low, Chief Economist of the Chief Department of Statistics in Kharkiv region

\section{Statistical Methods for Studying the Causality between Economic Growth and Material Welfare of Populations}

The article is devoted to the statistical methods and their applications in quantitative studies of the causality between economic phenomena and processes. Nowadays there is a great variety of mathematical, statistical and other methods of analysis. The problem of the study is how to select a statistical method in the right way. All the phenomena in the world are interrelated and affect each other. Therefore each observable phenomenon is causally related with innumerable other phenomena, and its pattern of development depends on the multiplicity of factors. In view of the above, the aim of the study is to get better understanding of these causalities. Learning of internationally established statistical methods is helpful. The capabilities of the statistical equations method infinding the above mentioned causalities are demonstrated, with emphasizing its advantages over other statistical methods. Comparative analysis of main statistical methods used in static and dynamic ways is given.

Keywords: statistical methods, statistical methodology, classification of statistical methods, correlation and regression analysis, method of the statistical equations of dependences.

\section{Посилання на статтю:}

Приданникова Ю. Є. Можливості статистичних методів для дослідження взаємозв'язків суспільно-економгінни явищ і процесів // Науковий вісник Національної академії статистики, обліку та аудиту: зб. наук. пр. 2017. № 3. Є. 16-25. 